\title{
Meishan Sections in South China: The Witness of the Largest Biological Mass Extinction during the Phanerozoic
}

\author{
Shuzhong SHEN*
}

\begin{abstract}
Spetacular Permian-Triassic sequences are exposed in a series of quarries at Meishan, Zhejiang Province in Southeast China. The Meishan sections have become the most intensively-studied sections to unravel the patterns and causes of the end-Permian mass extinction. Section D is the unique section with two Global Stratotype Section and Points (GSSPs) formally ratified by International Union of Geosciences. The Meishan Geopark is established.
\end{abstract}

Key words : Meishan sections, end-Permian, mass extinction, GSSP

\section{Introduction}

It has been well documented that the Phanerozoic experienced five big biological mass extinctions (Big Fives). Among them, the extinction happened at the end of Permian is the biggest (Sepkoski, 1981; Raup and Sepkoski, 1982; Erwin, 2006). About $95 \%$ of marine organisms were wiped out by an environmental catastrophe of a magnitude never seen before or since, and approximately $75 \%$ of animals and plants on land suffered similarly. Recovery of marine ecosystems following the end-Permian mass extinction was about 5 million years (mys) long and progressed very slowly until Middle Triassic (Payne et al., 2004; Lehrmann et al., 2006). Possible causes of the end-Permian mass extinction include an extremely fast, explosive release of methane or other gases such as carbon dioxide and hydrogen sulfide (Krull and Retallack, 2000; Ryskin, 2003; Shen S.Z. et al., 2011), increased volcanism (Campbell et al., 1992; Renne et al., 1995), coal/gas fires and

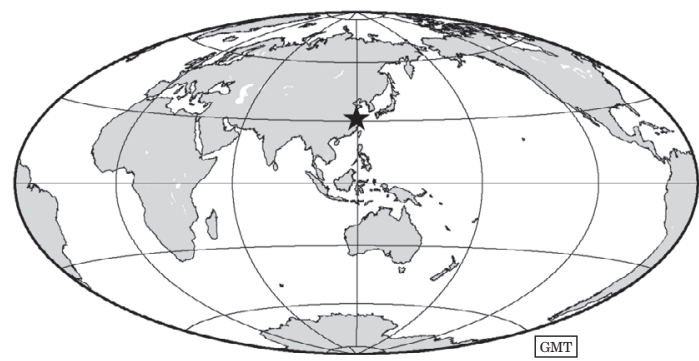

Fig. 1 Locality index map of the Meishan sections.

explosions from the Siberian Traps (Ryskin, 2003; Shen S.Z. et al., 2011; Darcy and Norman, 2012), multiple bolide impact events (Kaiho et al., 2001; Becker et al., 2004), oceanic anoxia (Wignall and Twitchett, 1996; Isozaki, 1997) and a shift in ocean circulation driven by climate change or a combination thereof (Erwin, 1994) etc. Recent extensive studies show that the Permian-Triassic boundary (PTB) sequences from shallow marine, slope to intra-platform basin are well developed in South China. These sequences recorded the

* State Key Laboratory of Palaeobiology and Stratigraphy, Nanjing Institute of Geology and Palaeontology, 39 East Beijing Road, Nanjing, 210008, China 

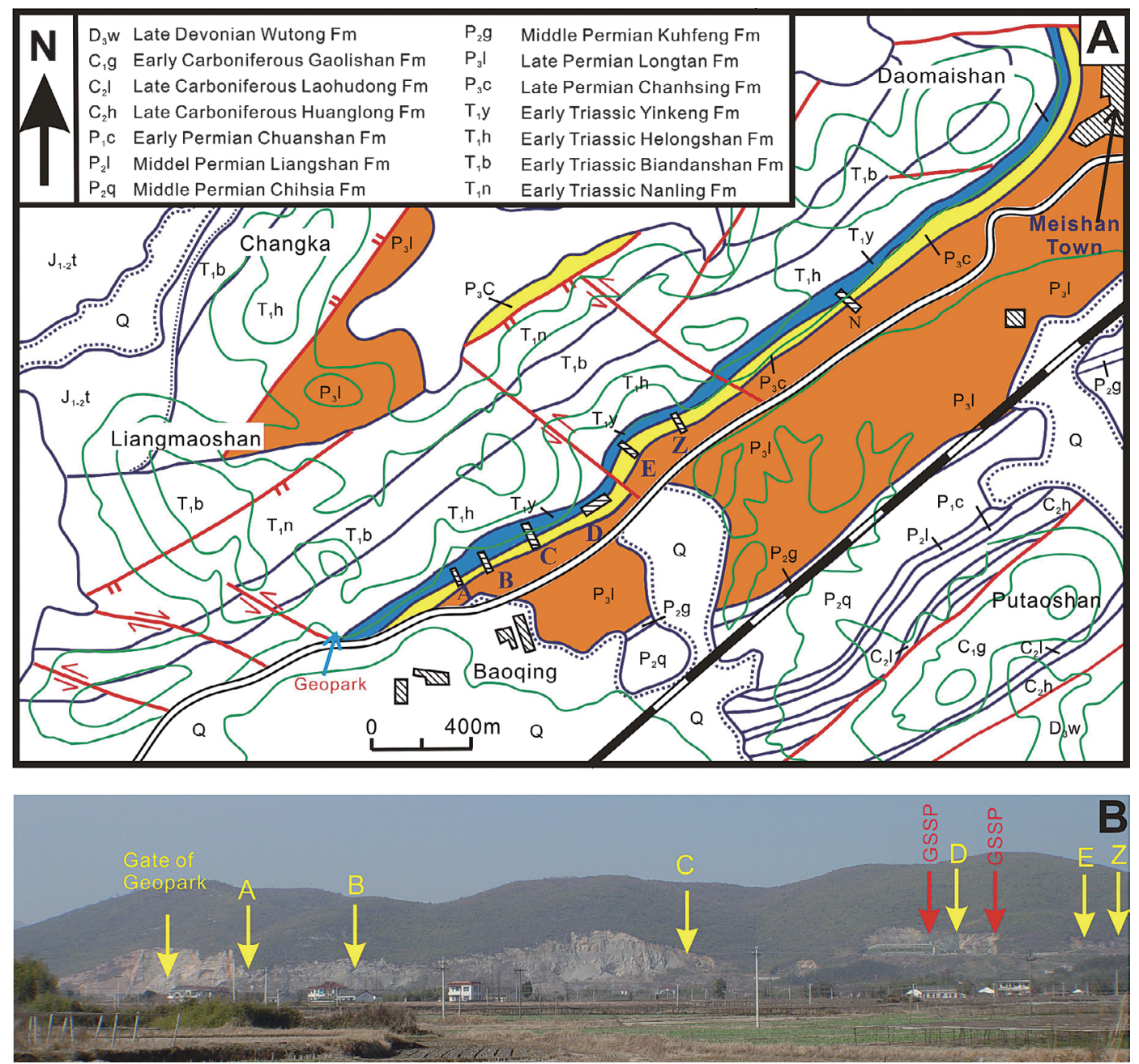

Fig. 2 A: geological map of the Meishan area in Zhejiang Province, China; B: a distal view of the series of sections from A to E, $\mathrm{Z}$ at Meishan.

whole process of the greatest dying and thereafter recovery in the earth history. Among them, the Permian-Triassic (P-Tr) sequence at the landmark Meishan sections (Figs. 1-2) has been visited by numerous worldwide scientists since it was discovered in the 1930s. They have become the most intensively-studied sections on the endPermian mass extinction in the world.

\section{Geological setting and stratigraphy}

Meishan is a small town and about $20 \mathrm{~km}$ to the Changxing County, Zhejiang Province in southeastern China (Fig. 2A). The Meishan sections (Section D: $31^{\circ} 4^{\prime} 50.38^{\prime \prime} \mathrm{N} ; 119^{\circ} 42^{\prime} 21.68^{\prime \prime} \mathrm{E}$ ) are about $2 \mathrm{~km}$ from the Meishan Town and have been well protected. The P-Tr lithological succession is very well exposed in a series of quarries from $\mathrm{A}$ to $\mathrm{E}$ and $\mathrm{Z}$ from west to east near the Meishan Town (Fig. 2B) which were excavated to use the limestone of the Changhsing Formation for construction. The type section for the Changhsing Limestone is located at Section D.

In Meishan, the Lopingian (Late Permian) Lungtan Formation is characterized by a coal- 


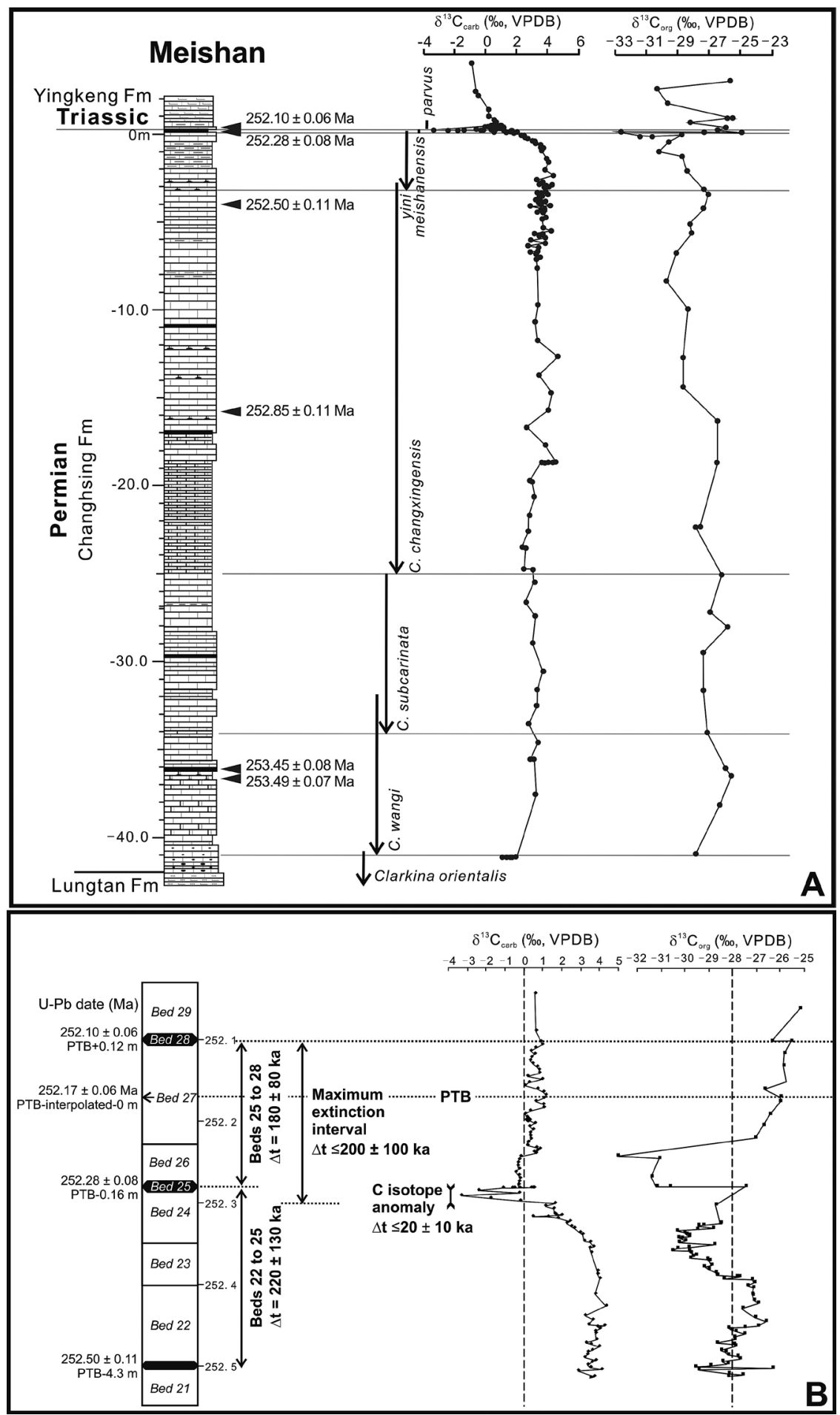

Fig. 3 Stratigraphical column with high-resolution conodont zones, geochronologic ages and both $\delta^{13} \mathrm{C}_{\text {carb }}$ and $\delta^{13} \mathrm{C}_{\text {org }}$ from the Meishan sections (Data from Cao et al., 2009; Shen S.Z. et al., 2011). 
bearing measure with highly diverse Gigantopteris flora and abundant marine fossils. Only the topmost part of this formation is exposed at the Meishan sections. This formation is of Wuchiapingian age. The Changhsing Formation is mainly composed of medium- to thick-bedded limestone containing highly diverse marine fossils including tens of different fossil groups such as conodonts, ammonoids, fishes, brachiopods, fusulinids, radiolarians and foraminifers, and dominated by slope facies deposits. This formation is about $46 \mathrm{~m}$ thick and contains abundant volcanic ash beds. The overlying Yinkeng Formation from the uppermost Changhsingian to the Lower Triassic is marked by a distinct ash bed (Bed 25) just below the PTB at the sections. It comprises two members; the lower member dominated by thinbedded micritic limestone with intercalations of shale and a few ash beds containing numerous disaster bivalve species, and the upper member, $170 \mathrm{~m}$ thick, consists of medium- to thick-bedded micritic limestone.

\section{High-resolution intergrative time framework and two GSSPs}

As a consequence of intensive studies of various aspects of stratigraphy, a high-resolution biostratigraphical framework based on conodonts and other fossils from the base of the sections (Wuchiapingian) to the Lower Triassic were established (Zhao et al., 1981; Mei et al., 1998; Yin et al., 2001; Zhang et al., 2007). The topmost part of the Lungtan Formation and the basal part of the Changhsing Formation is marked by the abundant occurrences of the conodont Clarkina orientalis and C. longicuspidata (Mei et al., 2004; Jin et al., 2006). Five conodont zones are recognized from the Changhsingian at the Meishan sections. They are the Clarkina wangi, C. subcarinata, C. changxingensis, C. yini, C. meishanensis-Hindeodus praeparvus zones in ascending order (Mei et al., 1998; Jiang et al., 2007; Zhang et al., 2007; Shen and Mei, 2010) (Fig. $3)$. The PTB is located in the middle part of a limestone bed (Bed 27) with a hardground, which may indicate short hiatus (Cao and Shang, 1998). The high-resolution integrated biostratigraphical successions for the Changhsingian Stage and the P-Tr transition at the Meishan sections have led to the ratifications of two Global Stratotype Section and Points (GSSPs) at the Meishan Section D by IUGS (Yin et al., 2001; Jin et al., 2006). Thus, the Meishan Section D has become the unique section with two GSSPs and a unit stratotype of the Changhsingian Stage is defined there (Fig. 4).

In addition to the detailed studies of biostratigraphy, the Meishan sections also contain volcanic ash beds and carbonized tuffs at about 35 different levels. Intensive dating based on uranium/lead ratios of zircons from the ash beds at the Meishan sections have been carried out by different international laboratories (Renne et al., 1995; Bowring et al., 1998; Mundil et al., 2004). Latest results using $\mathrm{U}-\mathrm{Pb}$ isotope dilution termal ionization mass epectrometry (ID-TIMS) have established a high-precision time framework of the Meishan sections. Seven ash beds from $\sim 40$ $\mathrm{m}$ of section were dated. Bed 6 (4.9 $\mathrm{m}$ above the base of the Changhsingian Stage) is $253.49 \pm$ $0.07 \mathrm{Ma}$. Bed 7 is $253.45 \pm 0.08 \mathrm{Ma}$. Bed 15 in the middle part of the Changhsingian yielded a date of $252.85 \pm 0.11 \mathrm{Ma}$. Bed $22(-4.5 \mathrm{~m}$ below the PTB) is $252.50 \pm 0.11 \mathrm{Ma}$. Bed 25 is 252.28 $\pm 0.08 \mathrm{Ma}$. Bed 28 is $252.10 \pm 0.06 \mathrm{Ma}$ (Fig. 3) (Shen S.Z. et al., 2011). The PTB is calculated by interpolation to be $252.17 \pm 0.06 \mathrm{Ma}$ and the Wuchiapingian/Changhsingian boundary is calculated by interpolation to be $254.14 \mathrm{Ma}$ based on the ages of ash beds relative to the first occurrence of Clarkina wangi at the Shangsi and Meishan sections (Fig. 3).

\section{The end-Permian catastrophic extinction}

Numerous critical results of palaeontological, geochronologic and geochemical data for the endPermian mass extinction have been reported from the Meishan sections. A statistic analysis of 15 marine fossil groups systematically collected from five sections at Meishan shows a catastrophic extinction happened at Bed 25 and experieniced no more than half mys (Jin et al., 2000) (Fig. 5). Latest dating of the ash beds around the P-Tr 

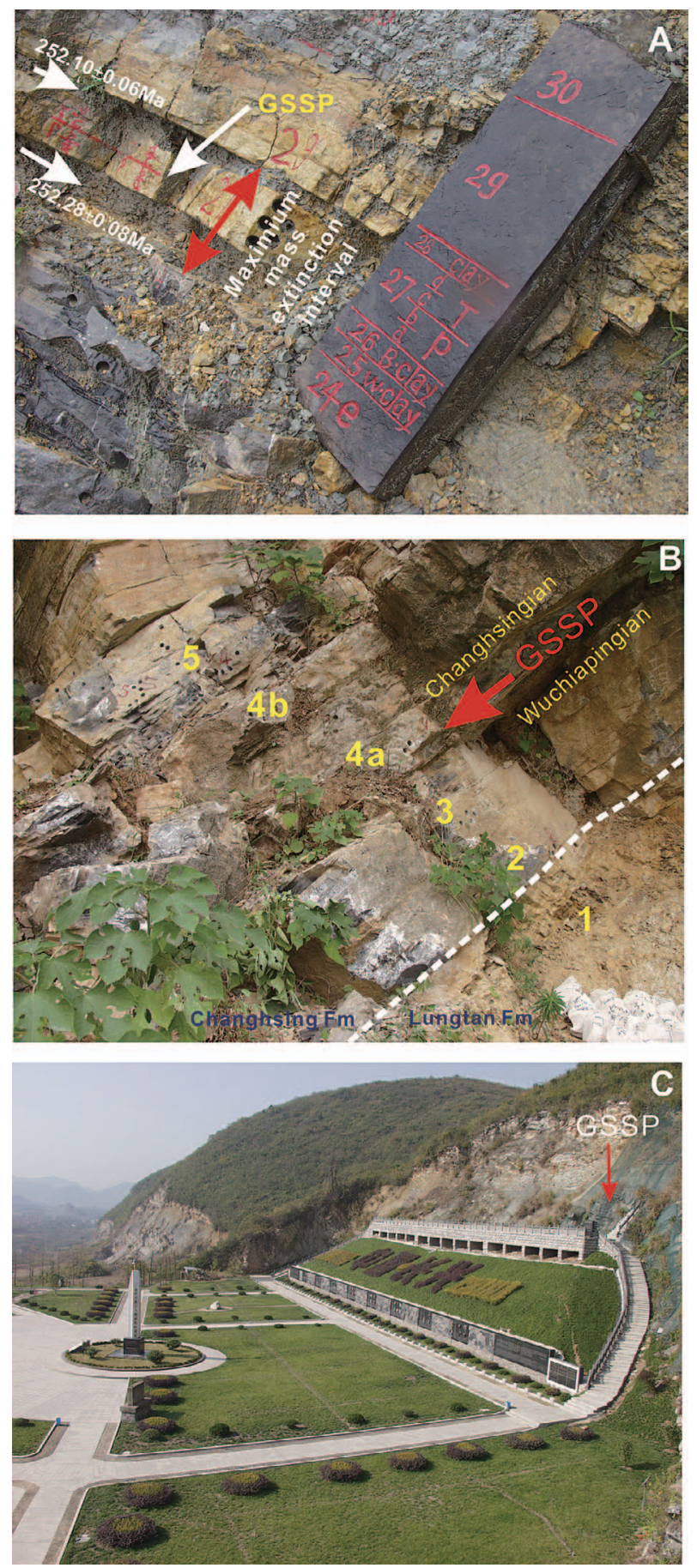

Fig. 4 The two Global Stratotype Section and Points (GSSPs) at the Meishan Section D showing the Permian-Triassic boundary (A) and Wuchiapingian-Changhsingian boundary (B). C: A photo showing the GSSP square of the Meishan Geopark with a monument approximately pointing the Permian-Triassic boundary in a distal quarry (Section C). 


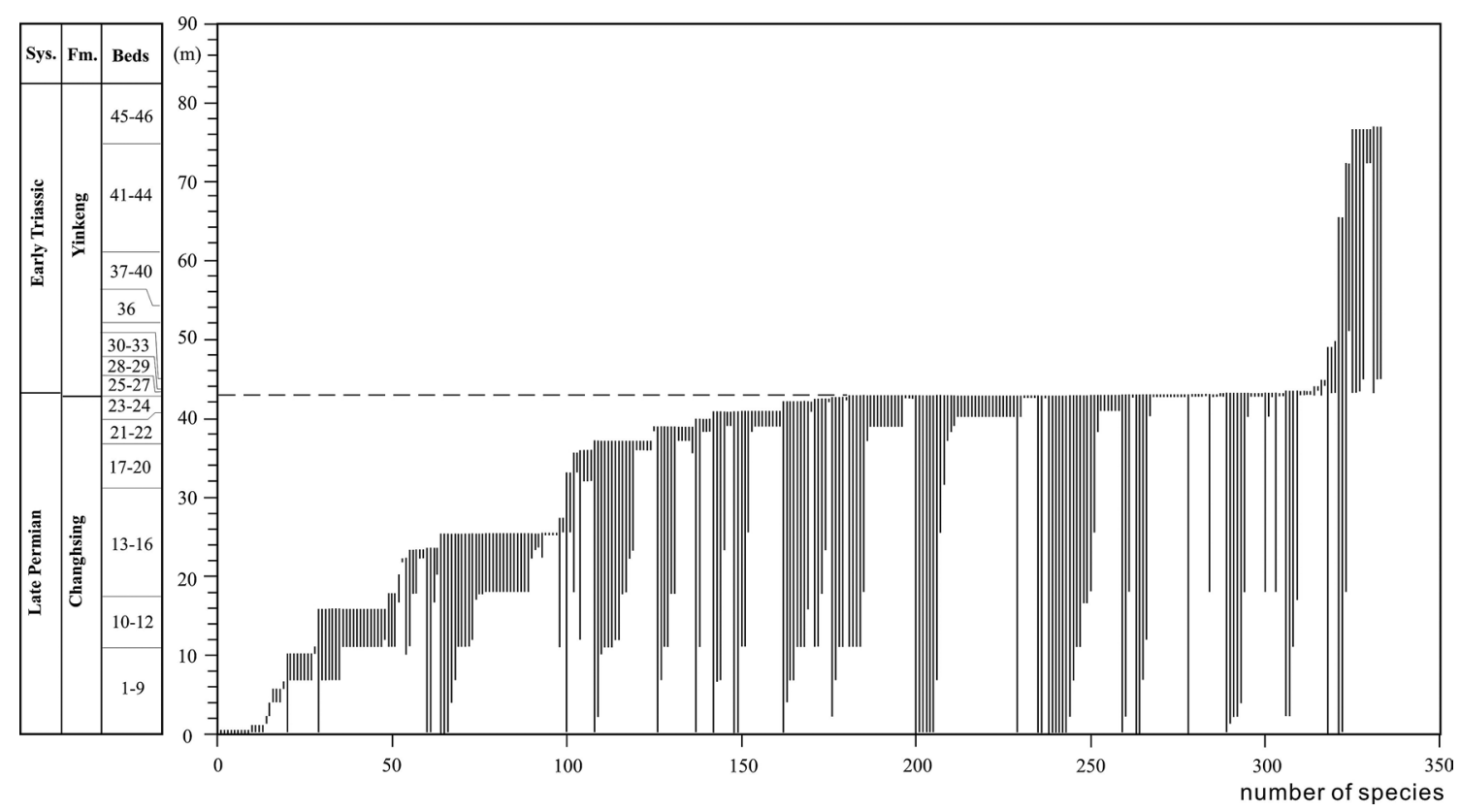

Fig. 5 The extinction pattern of the Meishan sections (after Jin et al., 2000).

transition at Meishan suggest that the main extinction event began in Bed $24 \mathrm{e}$ just before $252.28 \pm 0.08 \mathrm{Ma}$ (age of Bed 25) and lasted no longer than $200 \pm 100 \mathrm{Kyr}$ (from Bed 24e to Bed 28) (Fig. 3B). This extinction has been confirmed in a large geographic area both in the sea and on land based on statistic palaeontological data from tens of different marine and terrestrial sections in South China and Tibet (Shen S.Z. et $a l .$, 2011). On the other hand, some researchers have suggested multiple pulses of the extinction in various levels in the P-Tr transition (Feng et al., 2007; Yin et al., 2007; Song et al., 2009) and others suggested that the environmental deterioration resulted in the end-Permian mass extinction probably began from the Late Guadalupian (Middle Permian) associated with the breakup of the supercontinent Pangea, about 8 mys before the last catastrophe at the end of the Changhsingian (Isozaki et al., 2007; Yin et al., 2007; Isozaki, 2009).

Associated with the biological extinction, various geochemical studies suggest dramatic environmental changes around the extinction. A large, abrupt global negative shift of both $\delta^{13} \mathrm{C}_{\text {carb }}$ and $\delta^{13} \mathrm{C}_{\text {org }}$ coincides with this extinction (Fig. 3). At the Meishan sections, a progressive negative downturn in $\mathrm{C}$ isotopic composition of $2.4 \%$ over $1.79 \mathrm{~m}$ preceded the sudden drop was detected. This downturn is followed by a sharp $5 \%$ negative $\delta^{13} \mathrm{C}$ isotopic anomaly over $5 \mathrm{~cm}$ that starts abruptly within the topmost part of Bed 24e and ends in Bed 25 (Cao et al., 2002, 2009; Xie et al., 2007) and had a duration less than $20 \pm 10 \mathrm{Kyr}$ (Shen S.Z. et al., 2011) (Fig. $3 \mathrm{~B})$. Biomarkers and sulfur isotopes from the Meishan sections indicate that anoxic or euxinic conditions and microbial expansion prevailed the extinction interval (Grice et al., 2005; Xie et al., 2005; Cao et al., 2009; Shen Y. et al., 2011). Recent study based on oxygen isotope ratios measured on phosphate-bound oxygen in conodont apatite from the Meishan sections indicates that a very rapid climatic warming (an $8^{\circ} \mathrm{C}$ rise in temperature) is consistent with the extinction (Joachimski et al., 2012). Thus, an extremely fast, explosive release of methane and/or coal/gas fires and explosions triggered by Siberia flood volcanism becomes one of the most popular scenarios for the endPermian mass extinction (Ryskin, 2003; Shen S.Z. 
et al., 2011; Darcy and Norman, 2012; Payne and Clapham, 2012).

\section{The Meishan Geopark}

The Meishan sections, the most intensivelystudied section in the world with the unique Changhsingian body stratotype constarined by two GSSPs (Fig. 4), recorded the whole process of the end-Permian mass extinction. It has become the base for popular science for understanding the earth history. A geopark and an exceptional palaeontological museum were established there. The Meishan Geopark creates a rich storehouse to be explored for the P-Tr world, the GSSPs, volcanic ashes, the history of the largest mass extinction happened during the Phanerozoic and the local culture. The Meishan Museum exhibits a graphic illustration of the life history on the earth, various fossils, minerals and distinguished Chinese scientists who studied the Meishan sections. It has become the most popular site to visit for students in Southeast China and provides support to communicate geoscientific knowledge and environmental concepts to the public. It also fosters scientific research and cooperation with scientists all over the world.

\section{Acknowledgements}

The studies of the Meishan sections carried out by the Nanjing group are supported by National Science Foundation of China, the Ministry of Science and Technology and Chinese Academy of Sciences. I am grateful to all international collabrators with the Nanjing Group.

\section{References}

Becker, L., Poreda, R.J., Basu, A.R., Pope, K.O., Harrison, T.M., Nicholson, C. and Iasky, R. (2004): Bedout: A possible end-Permian impact crater offshore of Northwestern Australia. Science, 304, 1469-1476.

Bowring, S.A., Erwin, D.H., Jin, Y.G., Martin, M.W., Davidek, K. and Wang, W. (1998): U/Pb zircon geochronology and tempo of the end-Permian mass extinction. Science, 280, 1039-1045.

Campbell, I.H., Czamanske, G.K., Fedorenko, V.A., Hill, R.I. and Stepanov, V. (1992): Synchronism of the Siberian Traps and the Permian-Triassic boundary. Science, 258, 1760-1763.

Cao, C.Q. and Shang, Q.H. (1998): Microstratigraphy of Permo-Triassic transition sequence of the Meishan section, Zhejiang, China. in Permian Stratigraphy, Environments and Resources, Volume 2: Stratigraphy and Environments, Palaeoworld 9 edited by Jin, Y.G., Wardlaw, B.R. and Wang, Y., Hefei, University of Science and Technology of China Press, 147-152.

Cao, C.Q., Wang, W. and Jin, Y.G. (2002): Carbon isotope excursions across the Permian-Triassic boundary in the Meishan section, Zhejiang Province, China. Chinese Science Bulletin, 47, 1125-1129.

Cao, C.Q., Love, G.D., Hays, L.E., Wang, W., Shen, S.Z. and Summons, R.E. (2009): Biogeochemical evidence for euxinic oceans and ecological disturbance presaging the end-Permian mass extinction event. Earth and Planetary Science Letters, 281, 188-201.

Darcy, E.O. and Norman, H.S. (2012): Explosive eruption of coal and basalt and the end-Permian mass extinction. Proceedings of the National Academy of Sciences, 109, 59-62.

Erwin, D.H. (1994): The Permo-Triassic Extinction. Nature, 367, 231-236.

Erwin, D.H. (2006): Extinction: How Life on Earth Nearly Ended 250 Million Years Ago. New Jersey, Princeton University Press, 296p.

Feng, Q.L., He, W.H., Gu, S.Z., Meng, Y.Y., Jin, Y.X. and Zhang, F. (2007): Radiolarian evolution during the latest Permian in South China. Global and Planetary Change, 55, 177-192.

Grice, K., Cao, C.Q., Love, G.D., Bottcher, M.E., Twitchett, R.J., Grosjean, E., Summons, R.E., Turgeon, S.C., Dunning, W. and Jin, Y.G. (2005): Photic zone euxinia during the Permian-Triassic superanoxic event. Science, 307, 706-709.

Isozaki, Y. (1997): Permo-Triassic boundary superanoxia and stratified superocean: Records from lost deep sea. Science, 276, 235-238.

Isozaki, Y. (2009): Illawarra Reversal: The fingerprint of a superplume that triggered Pangean breakup and the end-Guadalupian (Permian) mass extinction. Gondwana Research, 15, 421-432.

Isozaki, Y., Kawahata, H. and Minoshima, K. (2007): The Capitanian (Permian) Kamura cooling event: The beginning of the Paleozoic-Mesozoic transition. Palaeoworld, 16, 16-30.

Jiang, H.S., Lai, X.L., Luo, G.M., Aldridge, R.A., Zhang, K.X. and Wignall, P.B. (2007): Restudy of conodont zonation and evolution across the $\mathrm{P} / \mathrm{T}$ boundary at Meishan section, Changxing, Zhejiang, China, environmental and biotic changes during the PaleozoicMesozoic transition. Global and Planetary Change, 55, 39-55.

Jin, Y.G., Wang, Y., Wang, W., Shang, Q.H., Cao, C.Q. and Erwin, D.H. (2000): Pattern of marine mass extinction near the Permian-Triassic boundary in South China. Science, 289, 432-436.

Jin, Y.G., Wang, Y., Henderson, C., Wardlaw, B.R., Shen, S.Z. and Cao, C.Q. (2006): The Global Boundary Stratotype Section and Point (GSSP) for the base of 
Changhsingian Stage (Upper Permian). Episodes, 29, 175-182.

Joachimski, M.M., Lai, X.L., Shen, S.Z., Jiang, H.S., Luo, G.M., Chen, B., Chen, J. and Sun, Y.D. (2012): Climate warming in the latest Permian and the PermianTriassic mass extinction. Geology, 40, 195-198.

Kaiho, K., Kajiwara, Y., Nakano, T., Miura, Y., Kawahata, H., Tazaki, K., Ueshima, M., Chen, Z.Q. and Shi, G.R. (2001): End-Permian catastrophe by a bolide impact: Evidence of a gigantic release of sulfur from the mantle. Geology, 29, 815-818.

Krull, E.S. and Retallack, G.J. (2000): $\delta^{13} \mathrm{C}$ depth profiles from paleosols across the Permian-Triassic boundary: Evidence for methane release. Geological Society of America Bulletin, 112, 1459-1472.

Lehrmann, D.J., Ramezani, J., Bowring, S.A., Martin, M.W., Montgomery, P., Enos, P., Payne, J.L., Orchard, M.J., Wang, H.M. and Wei, J.Y. (2006): Timing of recovery from the end-Permian extinction: Geochronologic and biostratigraphic constraints from south China. Geology, 34, 1053-1056.

Mei, S.L., Zhang, K.X. and Wardlaw, B.R. (1998): A refined succession of Changhsingian and Griesbachian neogondolellid conodonts from the Meishan section, candidate of the global stratotype section and point of the Permian-Triassic boundary. Palaeogeography Palaeoclimatology Palaeoecology, 143, 213-226.

Mei, S.L., Henderson, C.M. and Cao, C.Q. (2004): Conodont sample-population approach to defining the base of the Changhsingian Stage, Lopingian Series, Upper Permian. The palynology and micropalaeontology of boundaries. Geological Society Special Publications, 230, 105-121.

Mundil, R., Ludwig, K.R., Metcalfe, I. and Renne, P.R. (2004): Age and timing of the Permian mass extinctions: $\mathrm{U} / \mathrm{Pb}$ dating of closed-system zircons. Science, 305, 1760-1763.

Payne, J.L. and Clapham, M.E. (2012): End-Permian mass extinction in the Oceans: An ancient analog for the twenty-first century?. Annual Review of Earth and Planetary Sciences, 40, 89-111.

Payne, J.L., Lehrmann, D.J., Wei, J., Orchard, M.J., Schrag, D.P. and Knoll, A.H. (2004): Large perturbations of the carbon cycle during recovery from the endpermian extinction. Science, 305, 506-509.

Raup, D. and Sepkoski, J. (1982): Mass extinctions in the marine fossil record. Science, 215, 1501-1503.

Renne, P.R., Zhang, Z.C., Richards, M.A., Black, M.T. and Basu, A.R. (1995): Synchrony and causal relations between Permian-Triassic boundary crises and Siberian flood volcanism. Science, 269, 1413-1416.

Ryskin, G. (2003): Methane-driven oceanic eruptions and mass extinctions. Geology, 31, 741-744.
Sepkoski, J.J. (1981): A factor analytic description of the Phanerozoic marine record. Paleobiology, 7, 35-53.

Shen, S.Z. and Mei, S.L. (2010): Lopingian (Late Permian) high-resolution conodont biostratigraphy in Iran with comparison to South China zonation. Geological Journal, 45, 135-161.

Shen, S.Z., Crowley, J.L., Wang, Y., Bowring, S.A., Erwin, D.H., Sadler, P.M., Cao, C.Q., Rothman, D.H., Henderson, C.M., Ramezani, J., Zhang, H., Shen, Y., Wang, X.D., Wang, W., Mu, L., Li, W.Z., Tang, Y.G., Liu, X.L., Liu, L.J., Zeng, Y., Jiang, Y.F. and Jin, Y.G. (2011): Calibrating the end-Permian mass extinction. Science, 334, 1367-1372.

Shen, Y., Farquhar, J., Zhang, H., Masterson, A., Zhang, T.G. and Wing, B.A. (2011): Multiple S-isotopic evidence for episodic shoaling of anoxic water during Late Permian mass extinction. Nature Communications, 2, 1-5.

Song, H.J., Tong, J. and Chen, Z.Q. (2009): Two episodes of foraminiferal extinction near the Permian-Triassic boundary at the Meishan section, South China. Australian Journal of Earth Sciences, 56, 765-773.

Wignall, P.B. and Twitchett, R.J. (1996): Oceanic anoxia and the end Permian mass extinction. Science, 272, 1155-1158.

Xie, S.C., Pancost, R.D., Yin, H.F., Wang, H.M. and Evershed, R.P. (2005): Two episodes of microbial change coupled with Permo/Triassic faunal mass extinction. Nature, 434, 494-497.

Xie, S.C., Pancost, R.D., Huang, J.H., Wignall, P.B., Yu, J.X., Tang, X.Y., Chen, L., Huang, X.Y. and Lai, X.L. (2007): Changes in the global carbon cycle occurred as two episodes during the Permian-Triassic crisis. Geology, 35, 1083-1086.

Yin, H.F., Zhang, K.X., Tong, J.N., Yang, Z.Y. and Wu, S.B. (2001): The Global Stratotype Section and Point (GSSP) of the Permian-Triassic boundary. Episodes, 24, 275-275.

Yin, H.F., Feng, Q.L., Lai, X.L., Baud, A. and Tong, J.N. (2007): The protracted Permo-Triassic crisis and multi-episode extinction around the Permian-Triassic boundary. Global and Planetary Change, 55, 1-20.

Zhang, K.X., Tong, J.N., Shi, G.R., Lai, X.L., Yu, J.X., He, W.H., Peng, Y.Q. and Jin, Y.L. (2007): Early Triassic conodont-palynological biostratigraphy of the Meishan D Section in Changxing, Zhejiang Province, South China. Palaeogeography Palaeoclimatology Palaeoecology, 252, 4-23.

Zhao, J.K., Sheng, J.Z., Yao, Z.Q., Liang, X.L., Chen, C.Z., Rui, L. and Liao, Z.T. (1981): The Changhsingian and the Permian-Triassic boundary in South China. Bulletin of the Nanjing Institute of Geology and Palaeontology, 2, 1-112. 


\section{南中国，煤山セクショ \\ 一顕生代最大の大量絶滅の記録一}

沈樹忠*

中国南東部，浙江省の煤山採石場には一連の古 生代ペルム紀／中生代三畳紀の見事な連続層が露 出している。この地層断面はペルム紀末の大量絶 滅のパタンと原因を解明するため世界で最も詳し く研究されてきた。多産する化石の層序に加え て, 凝灰岩の正確な年代測定や炭素同位体比層序
が明らかにされている。中でも，国際地質科学連

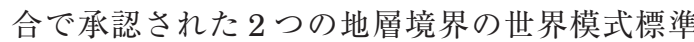
層序セクション・地点を含む Dセクションは, 重要である。最近, 煤山ジオパークがオープンし た。

$$
\text { キーワード：煤山セクション, ペルム紀末, 大量絶滅, 世界模式標準層序セクション・地点 }
$$

* 中国科学院南京地质古生物研究所现代古生物学和地层学实验室, 210008 中国江苏省南京市北京东路 39 号 